\title{
OPTIMALISASI PELAYANAN PUBLIK MELALUI PENDAMPINGAN PEMANFAATAN WEBSITE PEMERINTAH DESA KECAMATAN SUMBERPUCUNG KABUPATEN MALANG
}

\author{
Desinta Dwi Rapita*1, Didik Sukriono ${ }^{1}$, Nurul Ratnawati ${ }^{2}$, Meidi Saputra ${ }^{1}$ \\ desinta.fis@um.ac.id \\ 1Jurusan Hukum dan Kewargaengaraan, Fakultas IImu Sosial, Universitas Negeri Malang \\ ${ }^{2}$ Prodi Pendidikan IPS, Fakultas IImu Sosial, Universitas Negeri Malang \\ Diterima 14 April 2020, dipublikasikan 31 Oktober 2020
}

\begin{abstract}
Abstrak
Tujuan pengabdian ini untuk mengoptimalkan pelayanan publik dengan memanfaatkan website agar terwujud good village governance. Masyarakat pada era sekarang ini sangat membutuhkan pelayanan yang praktis dan efisien. Pemerintah desa di Kecamatan Sumberpucung Kabupaten Malang belum melaksanakan pelayanan publik yang diharapkan oleh masyarakat tersebut. Terdapat website Pemerintah Desa, namun belum dimanfaatkan dengan optimal, bahkan banyak perangkat desa yang tidak dapat mengoperasikan website tersebut. Metode pelaksanaan kegiatan ini dibagi menjadi tiga tahapan pelaksanaan, yaitu sosialisasi, workshop dan pendampingan. Hasil dari pelaksanaan pengabdian ini pemerintah desa memahami tentang tahapan-tahapan pemanfaatan website. Selanjutnya mereka juga berhasil membuat konten pelayanan publik pada website desa masingmasing dengan standar pelayanan publik yang sudah ditentukan. Pelayanan publik di pemerintahan desa dapat berjalan dengan optimal dengan memanfaatkan dan mengembangkan website pemerintah desa.
\end{abstract}

Kata Kunci: Pelayanan Publik, Website, Pemerintah Desa

\section{PENDAHULUAN}

Pemerintahan pada hakekatnya adalah pelayanan kepada masyarakat. Pemerintahan tidak diadakan untuk melayani dirinya sendiri, akan tetapi untuk melayani masyarakat dan menciptakan kondisi yang memungkinkan setiap anggota masyarakat mengembangkan kemampuan dan kreatifitasnya untuk mencapai tujuan bersama (Rasyid, 1998). Terbitnya Undang Undang Nomor 25 Tahun 2009 Tentang Pelayanan Publik (UUPP) membawa konsekuensi hukum bahwa setiap Pemerintah Desa wajib menyelenggarakan pelayanan publik dengan optimal agar terwujudnya good village governance. Hanya permasalahannya kinerja penyelenggara pelayanan publik, dilihat dari pola penyelenggaraan pelayanan masih jauh dari cita Undang-Undang Pelayanan Publik, yakni: kurang responsif, kurang informatif, kurang accessible, kurang koordinasi, cenderung birokratis, tidak mau mendengar keluhan, kritik dan saran, dan inefisien (Meiji et al., 2019). Sedangkan dari Sumber Daya Manusia (SDM), kurangnya profesionalisme, kurang kompetensi, kurang empati dan kurang etika. Lembaga Governance and Decentralization Survey menambahkan, bahwa buruknya pelayanan publik ditandai dengan masih besarnya diskriminasi pelayanan, tidak adanya kepastian pelayanan, rendahnya tingkat kepuasan masyarakat, bahkan pelayanan cenderung manjadi "komoditas".

Kementerian Dalam Negeri mencatat sebanyak 158 kepala daerah yang terdiri atas gubernur, bupati, wali kota tersangkut korupsi sepanjang tahun 2011 sampai dengan tahun 2014 . Sedikitnya 42 anggota DPR juga terseret korupsi pada kurun waktu 2008-2011 dan kurun waktu 2009-2011 terdapat 30 anggota DPR dari 4 parpol terlibat kasus dugaan suap pemilihan Deputi Gubernur Senior Bank Indonesia. Hal yang sama juga di institusi KPU, Komisi Yudisial, KPPU, Ditjen Pajak, Bank Indonesia dan BKPM. Sepanjang 2010, Mahkamah Agung menjatuhkan sanksi kepada 107 hakim, pegawai kejaksaan 288, dan 294 polisi yang dipecat dari dinas Polri (Kompas, 2011). 
Secara spesifik Sunaryati (2011) mengelompokkan bentuk "maladministrasi" dalam dua puluh katagori, yaitu: Kelompok pertama, bentuk maladministrasi yang terkait dengan ketepatan waktu dalam proses pelayanan umum, yang terdiri dari tindakan penundaan berlarut, tidak menangani dan melalaikan kewajiban; Kelompok kedua, bentuk maladministrasi yang mencerminkan keberpihakan sehingga menimbulkan rasa ketidakadilan dan diskriminasi, yang terdiri dari persekongkolan, kolusi, nepotisme, bertindak tidak adil, dan nyata-nyata tidak adil; Kelompok ketiga, bentuk maladministrasi yang lebih mencerminkan sebagai bentuk pelanggaran hukum dan peraturan perundangan, yang terdiri dari pemalsuan, pelanggaran undang-undang, dan perbuatan melawan hukum; Kelompok keempat, bentuk maladministrasi yang terkait dengan kewenangan/kompetensi atau ketentuan yang berdampak pada kualitas pelayanan umum pejabat publik kepada masyarakat, yang terdiri dari tindakan di luar kompetensi, pejabat yang tidak kompeten menjalankan tugas, intervensi yang mempengaruhi proses pemberian pelayanan umum, dan tindakan yang menyimpang prosedur tetap; Kelompok kelima, bentuk maladministrasi yang mencerminkan sikap arogansi seorang pejabat publik dalam proses pemberian pelayanan umum kepada masyarakat, yang terdiri dari tindakan sewenang-wenang, penyalahgunaan wewenang, tindakan yang tidak patut; Kelompok keenam,bentuk maladministrasi yang mencerminkan tindakan korupsi secara aktif, yang terdiri dari tindakan pemerasan atau permintaan imbalan uang, penguasaan barang orang lain tanpa hak dan penggelapan barang bukti.

Kecamatan Sumberpucung Kabupaten Malang mengalami banyak kemajuan. Dalam perkembangannya Kecamatan Sumberpucung mengalami pemekaran wilayah sehingga sekarang menjadi 7 desa, yaitu Desa Sumberpucung, Desa Jatigui, Desa Sambigede, Desa Senggreng, Desa Trenyang, Desa Ngebruk, dan Desa Karangkates. Namun, mayoritas Desa di Kecamatan Sumberpucung ini belum mempunyai Standar Pelayanan Publik. Kalau pun ada tapi belum bisa secara baik diterapkan. Sehingga untuk mewujudkan Good Village Governance akan sangat sulit. Sedangkan disisi lain masyarakat saat ini sangat membutuhkan pelayanan publik yang praktis dan efisien. Beberapa desa sudah memiliki website pemerintah desa, namun belum sepenuhnya dimanfaatkan karena keterbatasan pengetahuan. Oleh sebab itu, perlu diadakan pendampingan dalam proses optimalisasi pemanfaatan website Pemerintahan Desa sebagai upaya peningkatan pelayanan publik.

\section{METODE}

Kegiatan pengabdian dilakukan melalui aktifitas pelatihan dan pendampingan langsung kepada mitra (Wiradimadja et al., 2019). Metode pelaksanaan yang digunakan dalam pengabdian ini menggunakan 3 tahapan, yaitu: (1) tahap perencanaan, (2) tahap pelaksanaan, dan (3) tahap evaluasi. Tahap perencanaan adalah tahap awal untuk mempersiapkan segala sesuatu yang dibutuhkan dalam pelaksanaan program pengembangan desa mitra. Tim pengusul melakukan analisis situasi Pemerintahan Desa di Kecamatan Sumberpucung termasuk mendaftar permasalahan-permasalah yang dihadapi oleh masyarakat. Selanjutnya dari hasil analisis tersebut tim pengabdian melakukan persiapan dan perencanaan bentuk program yang harus dilaksanakan. Tahapan pelaksanaan program pengembangan desa ini menggunakan metode Participatory Action Research (PAR). Seluruh pihak yang relevan (stakeholders) dilibatkan secara aktif dalam mengkaji tindakan yang sedang berlangsung melalui kegiatan workshop. Setelah itu dilakukan tahap evaluasi atau refleksi. Pada tahap ini, pengusul dengan beberapa stakeholder yang terlibat melakukan Focus Group Discussion dengan model rembug. Hasi evaluasi dan refleksi dijadikan bahan koreksi untuk perbaikan dan peningkatan agar menjadi lebih baik lagi pelayanan publik di pemerintahan desa.

\section{HASIL DAN PEMBAHASAN}

Kecamatan Sumberpucung terdiri dari 7 (tujuh) desa, antara lain Desa Sumberpucung, Desa Jatiguwi, Desa Sambigede, Desa Senggreng, Desa Trenyang, Desa Ngebruk, dan Desa Karangkates. Total luas kecamatan adalah $3568 \mathrm{Km}^{2}$. Sebagian besar masyarakatnya bermata pencaharian di sektor pertanian, perikanan, perdagangan, perkebunan, buruh pabrik dan buruh bangunan. Masyarakat desa di Kecamatan Sumberpucung merupakan masyarakat yang sudah maju. Rata-rata sudah 'melek' teknologi. Mengenai urusan pelayanan terhadap administrasi di pemerintahan desa tentunya mereka 
juga mengharapakan pelayanan yang bisa efektif dan efisien. Namun, dari hasil analisis situasi yang dilakukan oleh tim pengabdian, di masing-masing Pemerintahan Desa di Kecamatan Sumberpucung belum sepenuhnya dapat memberikan pelayanan yang diinginkan oleh masyarakat. Bahkan terdapat beberapa desa yang belum mempunyai standar pelayanan publik sehingga prosedur pelayanan tidak jelas.

Kegiatan pengabdian kepada masyarakat ini dilaksanakan sebagai upaya untuk mengoptimalkan pelayanan publik pemerintahan desa di Kecamatan Sumberpucung Kabupaten Malang. Kegiatan utama dari pengabdian ini adalah melakukan pendampingan pemanfaatan website sebagai upaya untuk mengoptimalkan pelayanan publik. Oleh karena itu, perlu diawali dengan sosialisasi untuk memberikan informasi tentang pentingnya Standar Pelayanan Publik di Pemerintahan Desa. Subtansi pelayanan publik dibenahi terlebih dulu. Setelah itu dilakukan workshop pembuatan Standar Pelayanan Publik sesuai dengan kebutuhan masing-masing desa. Setelah masing-masing desa mempunyai Standar Pelayanan Publik, maka bentuk pelayanan publik dapat dikembangkan dengan memanfaatkan website desa.

Target utama kegiatan pengabdian ini adalah menghasilkan konten pelayanan publik pada website pemerintahan desa. Konten yang dimaksud secara khusus berisi tentang jenis-jenis pelayanan publik termasuk di dalamnya terdapat informasi-informasi atau berita tentang perkembangan desa.

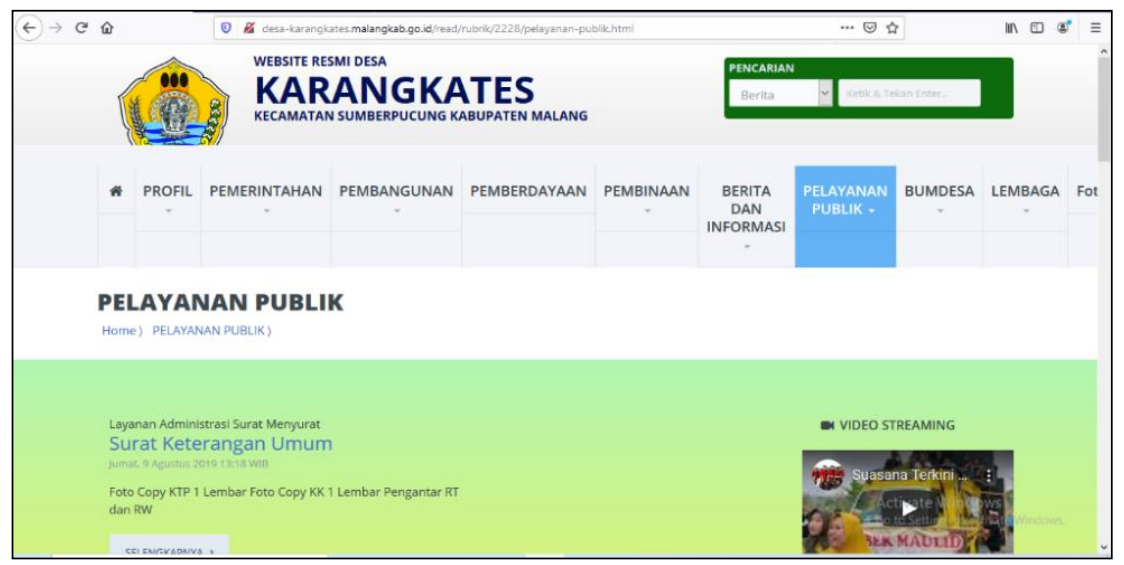

Gambar 1 Tampilan website Pemerintah Desa dengan penambahan konten pelayanan publik

Konten pelayanan publik yang dimaksud dapat dibedakan menjadi beberapa hal tergantung kebutuhan masing-masing desa. Misalnya saja berkaitan dengan humas dan pengaduan, layanan administrasi surat menyurat, layanan online polres malang, layanan pertanahan, layanan surat keterangan legalisasi (nikah, talak, cerai, rujuk) dan lain-lain.

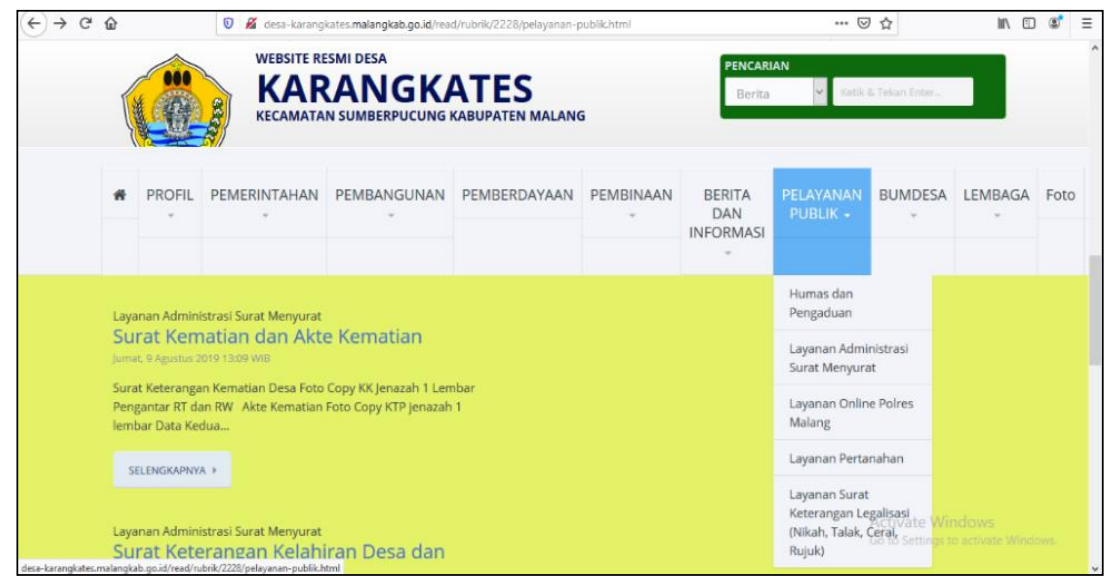

Gambar 2 Jenis-jenis pelayanan publik 
Kegiatan pengabdian kepada masyarakat dilaksanakan berdasarkan metode yang sudah ditentukan oleh Pelaksana. Terdapat 3 (tiga) tahap, yaitu perencanaan, pelaksanaan, dan evaluasi. Pada tahapan pertama atau perencanaan, Pelaksana melakukan melakukan analisis situasi Pemerintahan Desa di Kecamatan Sumberpucung termasuk mendaftar permasalahan-permasalahan yang dihadapi oleh masyarakat.

Selanjutnya dari hasil analisis tersebut maka tim pengusul melakukan persiapan dan perencanaan bentuk program yang harus dilaksanakan. Pelaksana sepakat melaksanakan workshop atau pelatihan pembuatan standar pelayanan publik dan pemanfaatan website Pemerintah Desa. Tahap berikutnya adalah pelaksanaan. Pada tahap ini, pelaksana menyelesaikan surat perizinan, yang pertama dari Lembaga Penelitian dan Pengabdian kepada Masyarakat. Dari surat itu Pelaksana menyampaikan permohonan ijin kepada Bakesbangpol Kabupaten Malang. Surat dari Bakesbangpol disampaikan kepada Camat Sumberpucung, mengingat Camat hanya bisa bertugas mengkoordinir Desa jika ada surat delegasi dan rekomendari dari Bakesbangpol.

Setelah itu Pelaksana menindaklanjuti dengan menyampaikan surat kepada Camat Sumberpucung dan langsung berkoordinasi dengan masing-masing Desa. Tim Pelaksana pada tahap pelaksanaan ini telah melaksanakan proses pendampingan untuk menganalisis hal-hal yang diperlukan di beberapa desa untuk membuat standar pelayanan publik.

Pelayanan publik merupakan kegiatan dalam rangka pemenuhan kebutuhan pelayanan sesuai dengan peraturan perundang-undangan bagi setiap warga negara dan penduduk atas barang, jasa dan/atau pelayanan administratif yang disediakan oleh penyelenggara pelayanan publik. Desa sebagai penyelenggara pelayanan publik harus menjalankan pelayanan publik yang sesuai dengan asas (UU Nomor 25 Tahun 2009): kepentingan umum, kepastian hukum, kesamaan hak, keseimbangan hak dan kewajiban, profesional, partisipatif, persamaan perlakuan atau tidak diskriminatif, keterbukaan, akuntabilitas, fasilitas dan perlakuan khusus bagi kelompok rentan, ketetapatan waktu, kecepatan, kemudahan dan keterjangkauan. Namun yang terjadi di hampir seluruh Desa di Sumberpucung masih belum diaktualisasikan. Perangkat desa belum benar-benar memahami konsep pelayanan publik yang ada di dalam Undang-Undang Nomor 25 Tahun 2009 tentang Pelayanan Publik sehingga peraturan tentang pelayanan publik belum bisa kami temukan di setiap desa. Bahkan temuan terakhir, kantor Kecamatan Sumberpucung pun juga belum menyusun dan menetapkan standar pelayanan publik yang sesuai dengan undang-undang. Mengenai penataan atau setting ruang pelayanan sudah mulai dibenahi, namun tetap menjadi masalah apabila tidak segera disusun standar pelayanan publik yang baik.

Tahap selanjutnya dari pelaksanaan pengabdian adalah workshop pembuatan Standar Pelayanan Publik dan pemanfaatan website Pemerintah Desa. Workshop dilaksanakan pada tanggal 7 Agustus 2019 bertempat di Kantor Kecamatan Sumberpucung Kabupaten Malang. Acara dihadiri oleh perangkat desa dari 7 desa di Kecamatan Sumberpucung yang terdiri dari kepala desa, sekretaris desa dan operator. Juga terdapat tambahan peserta dari Kecamatan Sumberpucung, yaitu sekretaris camat, kaur bidang pemerintahan, kaur hukum dan operator kecamatan. Total peserta yang hadir dan ditambah beberapa undangan menjadi 50 orang.
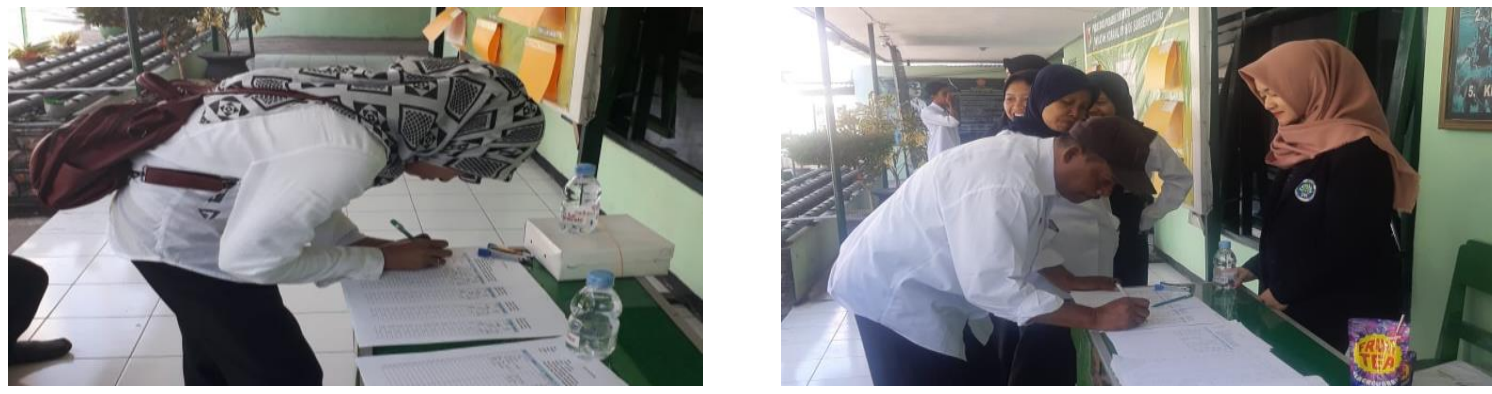

Gambar 3 dan 4 Peserta mengisi daftar hadir

Pemerintah Desa melalui tim yang dikirim untuk mengikuti workshop menyambut baik maksud dari Tim Pelaksana Pengabdian. Mereka juga merasa memerlukan untuk melaksanakan kegiatan ini 
dengan baik sebab akan memberikan manfaat yang banyak untuk memperbaiki sistem pelayanan publik di Desa masing-masing. Materi disampaikan oleh tim dengan sangat menarik. Secara bergantian, materi disampaikan oleh anggota tim pengabdian. Materi yang disampaiakan antara lain: konsep dasar Standar Pelayanan Publik, cara membuat Standar Pelayanan Publik, cara membuat konten Pelayanan Publik pada website Pemerintahan Desa, dan cara memanfaatkan website untuk pelayanan publik.
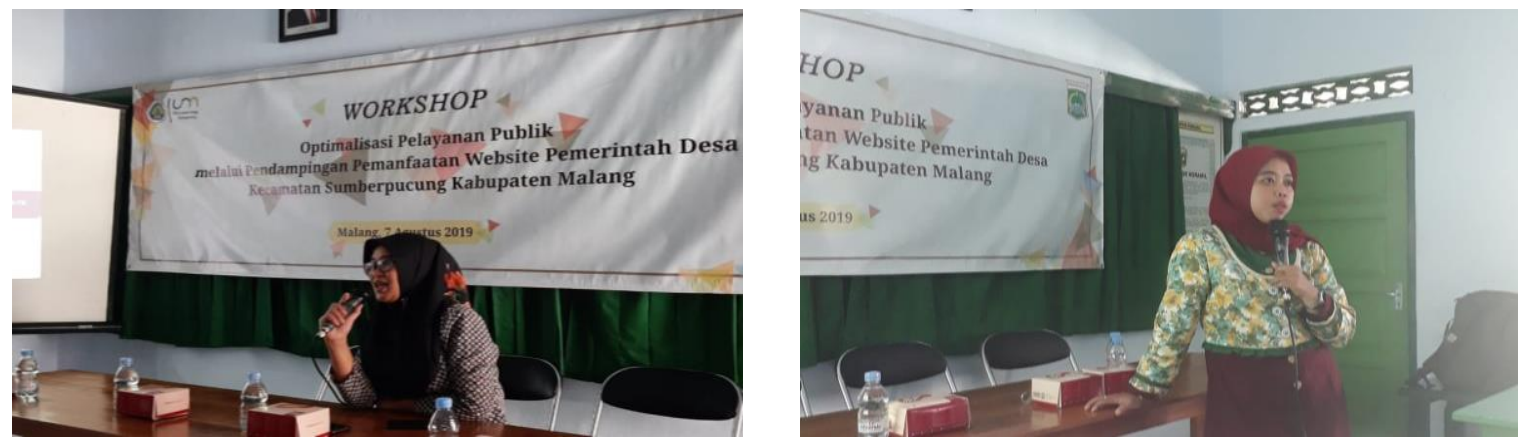

Gambar 5 Tim Pengabdian menyampaikan materi tentang Website dan Standar Pelayanan Publik

Pada saat praktik membuat Standar Pelayanan Publik dan juga praktik memanfaatkan website Pemerintah Desa, peserta sangat antusias. Banyak pertanyaan yg diajukan kepada tim pengabdian berkaitan dengan teknis pemanfaatan website dan cara menuliskan informasi dalam website sehingga bisa efektif untuk memberikan informasi kepada masyarakat sebagai bentuk pelayanan publik.
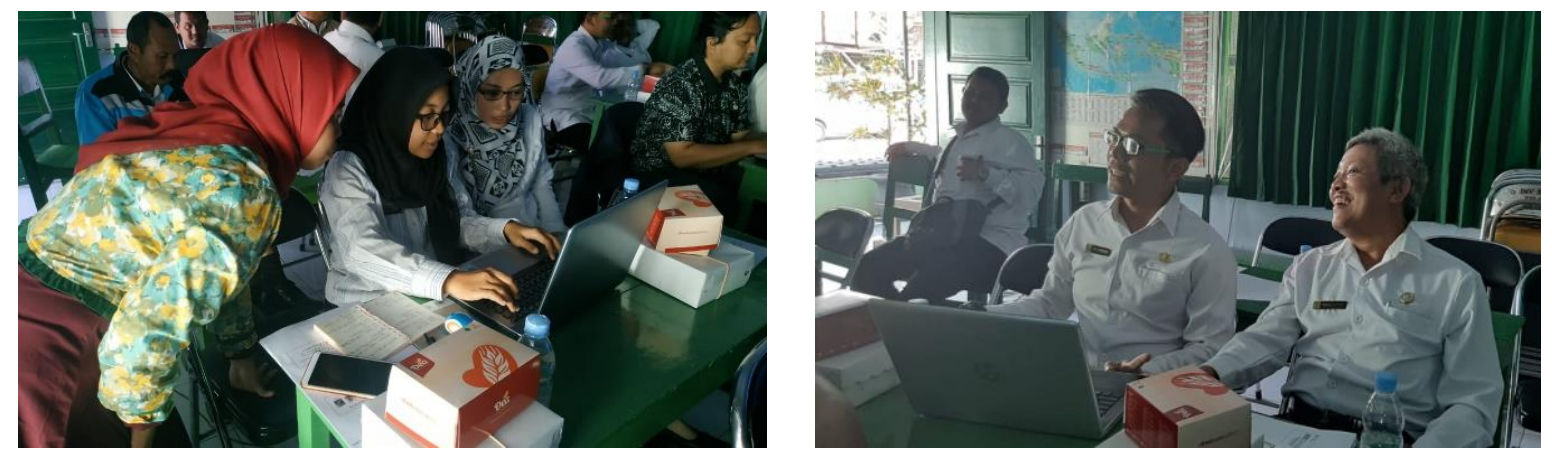

Gambar 6 Sesi Tanya-jawab peserta dan Tim Pengabdian

Beberapa peserta sudah berhasil membuat konten pelayanan publik pada website Pemerintahan Desa. Selanjutnya mereka mempraktekkan membuat informasi-informasi berkaitan dengan pelayanan publik di desa nya dan mulai praktek memanfaatkan konten yang mereka sudah buat. Selain itu seluruh perangkat desa (7 desa) sudah berhasil juga membuat Standar Pelayanan Publik.

Pada tahap selanjutkan dilaksanakan pendampingan di masing-masing desa di Kecamatan Sumberpucung. Pendampingan dilakukan oleh tim sesuai dengan jadwal yang sudah disepakati dengan perangkat desa khususnya para operator website. Pendampingan dilakukan pada minggu ke 2 dan ke 3 bulan September 2019. Sebagai persiapan, tim telah melaksanakan Focus Group Discussion (FGD) satu kali lagi dengan beberapa perangkat desa mewakili masing-masing desa (7 desa).

Hasil pendampingan yang dilakukan oleh tim yaitu para operator desa mulai mengembangkan bentuk pelayanan publik pada website pemerintahan desa. Konten pelayanan publik yang sudah berhasil dibuat sementara diisi dengan informasi-informasi pelayanan desa. Misalnya saja informasi mengenai humas dan pengaduan, layanan online Polres Malang, Layanan Pertanahan, layanan surat keterangan legalisasi (nikah, talak, cerai, rujuk), dan lain-lain. 
Beberapa sub layanan memang belum sepenuhnya diaktifkan sebab harus menindaklanjuti dengan pihak terkait, misalnya layanan online Polres Malang. Sedangkan layanan lainnya di beberapa website desa hanya diisi dengan informasi-informasi pelayanan desa. Walaupun begitu sudah sangat membantu warga untuk mendapatkan informasi. Misalnya saja tentang layanan administrasi surat menyurat atau layana surat keterangan legalisasi sudah diisi dengan informasi seperti persyaratan yang harus dibawa warga ke kantor desa apabila mereka ingin mengurus administrasi di desa.

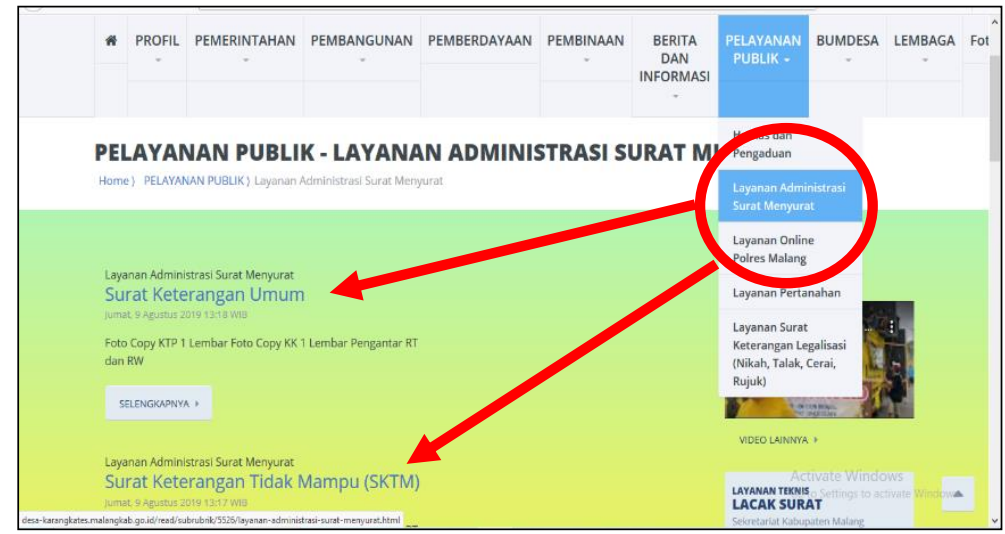

Gambar 7 Informasi tentang layanan administrasi surat menyurat

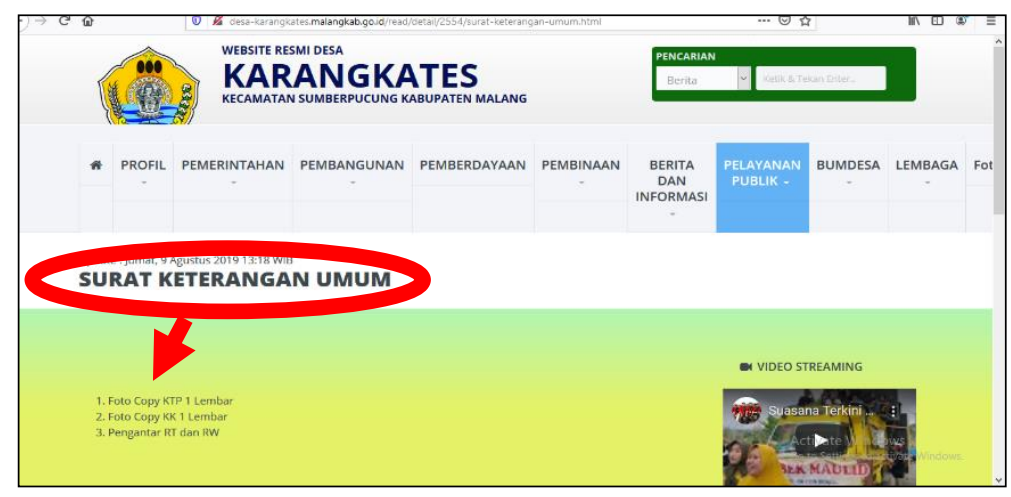

Gambar 8 Informasi tentang syarat pebuatan surat keterangan umum dari desa

Warga merasa sangat terbantu dengan adanya konten pelayanan publik di website pemerintahan desa. Mereka tidak perlu bolak-balik untuk mengambil persyaratan yang harus dipenuhi disaat mengurus surat keterangan dari desa. Mereka cukup cek dulu dari website persyaratannya, kemudian mereka melengkapi dulu baru mereka pergi ke kantor desa. Sehingga lebih efisien dan praktis.

\section{KESIMPULAN}

Kegiatan pengabdian kepada masyarakat di Pemerintahan Desa Kecamatan Sumberpucung Kabupaten Malang memberikan banyak manfaat. Beberapa hasil dari kegiatan pengabdian kepada masyarakat antara lain: 1) terbentuknya Standar Pelayanan Publik di masing-masing desa di Kecamatan Sumberpucung yang sesuai dengan peraturan perundang-undangan yang berlaku. 2) Pemerintahan Desa sudah berhasil mengembangkan website di Pemerintahan Desa dan dilengkapi dengan konten khusus pelayanan publik. Sehingga pelayanan publik di Pemerintahan Desa bisa berjalan dengan optimal. Banyak masyarakat yang merasa terbantu dengan adanya konten pelayanan publik karena lebih praktis dan efisien. 


\section{UCAPAN TERIMA KASIH}

Ucapan terima kasih tim pengabdian sampaikan kepada semua pihak yang telah membantu kelancaran dan keberhasilan kegiatan pengabdian ini. Dukungan yang luar biasa dari Universitas Negeri Malang selaku pemberi dana. Berikutnya Pemerintah Kabupaten Malang yang telah memberikan ijin dan juga memfasilitasi kerjasama tim dengan pihak Pemerintah Desa, dalam hal ini Kecamatan Sumberpucung dan Pemerintah Desa Sumberpucung, Desa Jatiguwi, Desa Sambigede, Desa Senggreng, Desa Trenyang, Desa Ngebruk, dan Desa Karangkates. Semua tim pengabdian dan perangkat desa yang terlibat, serta semua pihak yang tidak dapat disebutkan satu persatu.

\section{DAFTAR PUSTAKA}

Agus Dwiyanto, Mewujudkan Good Governance, Gajah Mada, Yogyakarta, 2005.

Agus Dwiyanto (et.al), Kinerja Tata Pemerintahan Daerah di Indonesia, PSKK UGM Bekerjasama dengan kemitraan, Yogyakarta, 2007.

Abdul Mukthie Fadjar, "Keprihatinan Memudarnya Penegakan Hukum dan Kewibawaan Hukum Di Indonesia", Makalah disampaikan pada serasehan Forum Doktor, Fakultas Hukum Universitas Brawijaya, 30 Juni 2011.

Agung Hendarto, Nizar Suhendra, Good Governance dan Penguatan Institusi Daerah, Masyarakat Transparansi Indonesia (MTI), Jakarta, 2002.

C.F.G. Sunaryati Hartono, Panduan Investigasi Untuk Ombudsman Indonesia, Jakarta, 2003.

Chambliss William J., dan Robert B. Seidman, Law, Order and Power, Addison-Westley, Mass, 1971.

Huntington, Samuel P. dan Joan Nelson, Partisipasi Politik di Negara Berkembang, Rineka Cipta, Jakarta, 1994.

Erwan Agus Purwanto dan Wahyudi Kumorotomo, Birokrasi Publik dalam Sistem Politik Semi Parlementer, Gava Media, Yogyakarta, 2005.

Habibi, Muhammad Mujtaba, Didik Sukriono, dkk. Pendampingan Pembentukan Standar Pelayanan Publik Pemerintahan Desa sebagai Upaya Mewujudkan Good Village Governance. Jurnal Pengabdian dan Dedikasi Sosial (JPDS) (April, 2019), Vol. 2, No 1 h.19-27

Jimly Asshiddiqie, Konstitusi dan Konstitusionalisme Indonesia, Jakarta, Konstitusi Press, 2005.

M. Ryaas Rasjid, Desentralisasi Dalam Menunjang Pembangunan Daerah Dalam Pembangunan Administrasi di Indonesia, Pustaka LP3ES, Jakarta, 1998.

Meiji, N., Widianto, A., Kodir, A., \& Irawan, I. (2019, June 17). Strengthening Village Information System to Reach Good Governance in Rural Areas through Participatory Rural Appraisal. Proceedings of 1st Workshop on Environmental Science, Society, and Technology, WESTECH 2018, December 8th, 2018, Medan, Indonesia. https://eudl.eu/doi/10.4108/eai.8-12-2018.2283894

MP3 Masyarakat Peduli Pelayanan Publik, Ada Apa dengan UU No. 25 Tahun 2009 tentang Pelayanan Publik?, Yayasan TIFA, Jakarta.

Satjipto Rahardjo, Penegakan Hukum Suatu Tinjauan Sosiologis, Penerbit Genta Publishing, Yogjakarta, 2009.

Sirajjudin, Didik Sukriono dan Winardi, Hukum Pelayanan Publik Berbasis Partisipasi dan Keterbukaan Informasi, Setara Press (Kelompok Insrans Publishing), Malang, 2011.

Soedjono Dirdjosisworo, Pengantar IImu Hukum, CV. Rajawali, Jakarta, 1984.

Solly Lubis, Politik dan Hukum di Era Reformasi, CV. Mandar Maju, Bandung, 2000.

Wiradimadja, A., Kurniawan, B., \& Sukamto. (2019). PELATIHAN DAN PENDAMPINGAN PENYUSUNAN PTK (PENELITIAN TINDAKAN KELAS) BAGI GURU IPS SMP/MTS MALANG RAYA. Jurnal Praksis Dan Dedikasi Sosial (JPDS), 2(1). 